VERSITA

DOI: 10.2478/tperj-2013-0003

\title{
Reference Values and Gender Differences of the Functional Parameters in Romanian Elite Junior Tennis Players
}

\author{
Adrian NAGEL ${ }^{1}$, Claudiu AVRAM ${ }^{2}$
}

\begin{abstract}
Purpose: To establish the reference values and gender differences regarding fitness, strength, and time reaction of the Romanian elite junior tennis players. Material and Methods: Thirty four junior tennis players (19 male, 15 female) with a mean age of 15 years were selected from the database of the Cardiopulmonary Effort Testing and Physical Performance Laboratory from Faculty of Physical Education and Sport, West University of Timisoara. To be included in the study, a tennis player had to belong to the Romanian Tennis Federation as a junior, be among the 50 best players in his/her category, and have no pathology at the evaluation moment. All subjects underwent functional evaluation by performing a maximal cardiopulmonary exercise test, the counter movement jump test and complex opto-acoustic reaction test. Results: The functional performance are significantly different for males and females in all parameters studied, with male tennis players showing better performance than female tennis players. Conclusions: The mean values of functional parameters of the Romanian elite junior tennis players are lower than international competitive tennis athletes. There are significant gender differences in junior tennis players. We hope that the present study results provide useful reference values for coaches and physical trainers in order to improve functional performance of their junior tennis players.
\end{abstract}

Key words: tennis, functional performance, fitness, strength, complex reaction

\section{Rezumat}

Scop: Stabilirea valorilor de referință şi diferențele de gen dintre acestea în ceea ce priveşte condiția fizică, puterea şi timpul de reacție a jucătoriilor practicanți ai tenisului de câmp în campionatul national de juniori. Material şi metode: treizeci şi patru de jucători de tenis juniori (19 bărbați, 15 femei), cu o vârstă medie de 15 ani au fost selectați din baza de date a laboratorului de testare cardiopulmonară la efort şi evaluare a performanței motrice a Facultății de Educație Fizică şi Sport, Universitatea de Vest din Timişoara. Pentru a fi incluşi în studiu, fiecare jucator de tenis trebuia să fie înregistrat ca junior în cadrul Federației Române de Tenis şi să fie printre cei mai buni 50 de jucători din categoria sa. Toți subiecții au urmat o evaluare funcțională prin efectuarea unei testări cardiopulmonare la efort de tip maximal, testul săriturii maximale în înălțime şi a testul de reacție complexă la stimuli opto-acustici. Rezultate: performanțele funcționale sunt semnificativ diferite pentru bărbați şi femei pentru toți parametrii studiați, juniorii practicanți ai tenisului de câmp de sex masculin având o performanță superioară celor de sex feminin. Concluzii: Valorile medii ale parametrilor funcționali ai jucătoriilor practicanți ai tenisului de câmp în campionatul național de juniori sunt mai mici decât cele ale sportivilor competitivi pe plan internațional. Există diferențe semnificative între sexe la jucători de tenis juniori. Sperăm ca rezultatele acestui studiului să furnizeze o sursă pentru valorile de referință ale parametrilor funcționali, pentru antrenori şi preparatori fizici, în scopul de a îmbunătăți performanța sportivă a practicanților tenisului de câmp la nivel de juniori.

Cuvinte cheie: tenis, performanță, forță, putere, reacție complexă.

\footnotetext{
${ }^{1}$ Lecturer PhD, Physical Education and Sport Faculty, West University of Timisoara, e-mail: adriannagel@yahoo.com

${ }^{2}$ Associate Professor, MD, PhD, Physical Education and Sport Faculty, West University of Timisoara, claudiu.avram@gmail.com
} 


\section{Introduction}

Tennis is characterized as a short-duration and high intensity sport that is physically demanding on the body. Age, gender, physical, technical and psychological components will all influence the performance of the tennis player. Optimal planning and training programmes will improve the safety and effectiveness of players game [1].

Improving training sessions and optimizing the profile of the junior tennis players requires a good knowledge of functional parameters (strength, power, endurance, heart rate, etc.), that can contribute to the tennis player's profile and consequently should be take into account when planning training sessions [2].

To our knowledge, no study has evaluated these functional parameters in Romanian elite junior tennis players. This is extremely useful to improve performance, and for prevention and rehabilitation of sport injuries, especially in younger tennis players. Therefore, our aim is to establish the average values and gender differences regarding fitness, strength, and time reaction of the Romanian elite junior tennis players.

\section{Material and Methods}

Thirty four junior tennis players (19 male, 15 female) with a mean age of 15 years (range, 12-16) were selected from the database of the Cardiopulmonary Effort Testing and Physical Performance Laboratory from Faculty of Physical Education and Sport, West University of Timisoara. Mean weight for male and female players was $64.3 \pm 8.6$ and $49.8 \pm 10.9 \mathrm{~kg}$, respectively, and mean height was $175.7 \pm 6.4$ and $159.8 \pm 11.9 \mathrm{~cm}$. To be included in the study, a tennis player had to belong to the Romanian Tennis Federation as a junior, be among the 50 best players in his/her category, and have no pathology at the evaluation moment.

The Isometric muscle strength evaluation was performed using a digital manometric dynamometer (Chatillon K-FCE-200, USA). Taking into account the individual needs of athletes, we evaluat following muscle groups as important determinants of physical performance in tennis: flexors, internal rotator and abductor muscles of the arm. We present in the following paragraphs the evaluation methodology for the three most important muscle groups on the dominant side of the tennis players:

1. The arm internal rotators isometric strength was tested from the position of maximal external rotation of the shoulder, arm resting on a table and elbow at 90 degree, with the dynamometer placed on the wrist.

2. The arm abductors isometric strength was tested with the subject in standing position and the nondominant side in contact with a wall. The dominant superior limb was placed in the anatomic position with the dynamometer placed on the external epicondyle.

3. The forearm flexors isometric strength was tested from the position of 90 degree flexion of the arm and forearm; arm resting on a table, with the dynamometer placed on the wrist.

The aerobic fitness was evaluated after performing a maximal cardiopulmonary exercise test (using a Metalyzer 3B gas exchange device, Germany) on bicycle ergometer (Lode Corival, Holland). We recorded peak oxygen uptake ( $\left.\mathrm{V}^{\prime} \mathrm{O} 2_{\text {peak }}\right)$, oxygen uptake at anerobic threshold (V'O2_AT), and respiratory equivalents for oxygen $\left(\mathrm{VE} / \mathrm{V}^{\prime} \mathrm{O} 2\right)$ and carbon dioxide (VE/V'CO2).

All subjects underwent measurements of explosive power of the lower limbs by performing the Counter 
movement jump test and Complex opto-acoustic reaction test (using Optojump Next system, Italy). The time reaction was assessed in each subject by making a move outside a perimeter and reaching a target located at a distance of 1 meter and 25 centimetres from the floor - this type of movement involved, in different proportions, the lower limbs muscles, trunk and upper limbs muscles, along with coordination skills, and explosive power.

\section{Results and discussions}

Providing training sessions for tennis players requires a good understanding of the physiological variables important to optimize performance. Tennis requires short explosive bursts of energy repeated many times per match or practice session. A tennis match because is not limited in time (unlike many other sports), may last less than one hour or as long as five hours (in five-set matches). This situation requires tennis athletes to have high endurance and fitness in order to be successful and avoid injury [1].

Our study results shows that evaluated parameters are significantly different for males (Table I and Table II) and females (Table III and Table IV) in all parameters studied, with male tennis players showing better performance than female tennis players.

Table I. The endurance and aerobic fitness performance of the Romanian male junior tennis players

\begin{tabular}{lcccc} 
& V'O2_AT (ml/min/kg) & V'02_peak (ml/min/kg) & VE/V'O2 & VE/V'CO2 \\
\hline Minimum & 17.0 & 30 & 30.5 & 25.5 \\
25\% Percentile & 24.0 & 38 & 31.1 & 29.4 \\
Median & 29.0 & 44 & 35 & 31.7 \\
$75 \%$ Percentile & 36.0 & 47 & 38 & 34.3 \\
Maximum & 45.0 & 59 & 39.4 & 37.5 \\
Mean & 30.2 & 43.2 & 34.7 & 31.9 \\
Std. Deviation & 7.3 & 8.4 & 3.1 & 3.2 \\
Variation Coefficient (\%) & 24.2 & 19.4 & 8.9 & 10.1 \\
\hline
\end{tabular}

Table II. The strenght and power performance of the Romanian male junior tennis players

\begin{tabular}{lcccccc}
\hline & $\begin{array}{c}\text { Forearm } \\
\text { flexion (KgF) }\end{array}$ & $\begin{array}{c}\text { Arm internal } \\
\text { rotation (Kg) }\end{array}$ & $\begin{array}{c}\text { Arm } \\
\text { abduction } \\
\text { (KgF) }\end{array}$ & $\begin{array}{c}\text { Jump height } \\
\text { (cm) }\end{array}$ & $\begin{array}{c}\text { Explosive } \\
\text { power } \\
\text { (W/Kg) }\end{array}$ & $\begin{array}{c}\text { Time } \\
\text { reaction (s) }\end{array}$ \\
\hline Minimum & 14.9 & 8.8 & 14 & 22.5 & 13.0 & 1.31 \\
25\% Percentile & 20.9 & 15 & 22.5 & 31.1 & 16.6 & 1.32 \\
Median & 27.3 & 20 & 27.9 & 36.3 & 41.7 & 1.32 \\
75\% Percentile & 31.8 & 23.5 & 31.5 & 44.7 & 62.8 & 1.35 \\
Maximum & 35.5 & 28.7 & 41 & 49.5 & 74.5 & 1.46 \\
Mean & 26.4 & 19.5 & 27.3 & 36.6 & 40.5 & 1.34 \\
Std. Deviation & 6 & 5.4 & 6.9 & 8.4 & 22.6 & 0.04 \\
Variation Coefficient (\%) & 22.8 & 27.8 & 25.2 & 22.9 & 55.7 & 2.6 \\
\hline
\end{tabular}


Table III. The endurance and aerobic fitness performance of the Romanian female junior tennis players

\begin{tabular}{lcccc}
\hline & V'O2_AT (ml/min/kg) & V'O2_peak (ml/min/kg) & VE/V'O2 & VE/V'CO2 \\
\hline Minimum & 17 & 24 & 30.7 & 25.6 \\
25\% Percentile & 23 & 33 & 31.3 & 29.4 \\
Median & 28 & 39 & 35.2 & 32 \\
$75 \%$ Percentile & 35 & 45 & 38.1 & 34.5 \\
Maximum & 45 & 49 & 39.7 & 37.9 \\
Mean & 28.9 & 38.4 & 34.8 & 32.2 \\
Std. Deviation & 7.7 & 7.9 & 3.2 & 3.2 \\
Variation Coefficient (\%) & 26.5 & 20.7 & 9.1 & 10.1 \\
\hline
\end{tabular}

Table IV. The strenght and power performance of the Romanian female junior tennis players

\begin{tabular}{lcccccc}
\hline & $\begin{array}{c}\text { Forearm } \\
\text { flexion (KgF) }\end{array}$ & $\begin{array}{c}\text { Arm internal } \\
\text { rotation (Kg) }\end{array}$ & $\begin{array}{c}\text { Arm } \\
\text { abduction } \\
\text { (KgF) }\end{array}$ & $\begin{array}{c}\text { Jump height } \\
\text { (cm) }\end{array}$ & $\begin{array}{c}\text { Explosive } \\
\text { power } \\
\text { (W/Kg) }\end{array}$ & $\begin{array}{c}\text { Time } \\
\text { reaction (s) }\end{array}$ \\
\hline Minimum & 13 & 8.4 & 13.4 & 18.2 & 10.7 & 1.32 \\
25\% Percentile & 15.4 & 9.9 & 16.4 & 24.6 & 16.9 & 1.43 \\
Median & 16.3 & 11.4 & 18.4 & 28.5 & 22.6 & 1.49 \\
75\% Percentile & 19.4 & 15.2 & 22.4 & 32.9 & 35.8 & 1.53 \\
Maximum & 20.8 & 17.2 & 24.6 & 36.1 & 67.7 & 1.54 \\
Mean & 16.9 & 12.2 & 19.1 & 28.3 & 27.8 & 1.48 \\
Std. Deviation & 2.4 & 2.9 & 3.5 & 5.4 & 15.4 & 0.06 \\
Variation Coefficient (\%) & 13.9 & 24.2 & 18.4 & 19.2 & 55.6 & 4.3 \\
\hline
\end{tabular}

Cardiopulmonary exercise testing (CPET) is considered the gold standard for aerobic exercise capacity assessment [3]. Competitive male tennis athletes have maximal oxygen uptake values 50 to $65 \mathrm{ml} / \mathrm{min} / \mathrm{kg}$ [4]. Differences in peak oxygen uptake have been observed in relation to age - the lowest values have been found in youth, while junior players have higher values [5]. Regarding oxygen uptake during a tennis match, the average values are 23 - $40 \mathrm{ml} / \mathrm{min} / \mathrm{kg}$. However, these values represent an average intensity of approximately 50$60 \%$ of the V'O2peak, and this value is higher when the level of the player is lower [2].

Our study shows that in both sexes, all variables related to endurance (VO2_AT) and aerobic fitness (V'O2 ${ }_{\text {peak }}$ ) performance were significantly greater $(p<0.001)$ for man then women. (Figure 1)

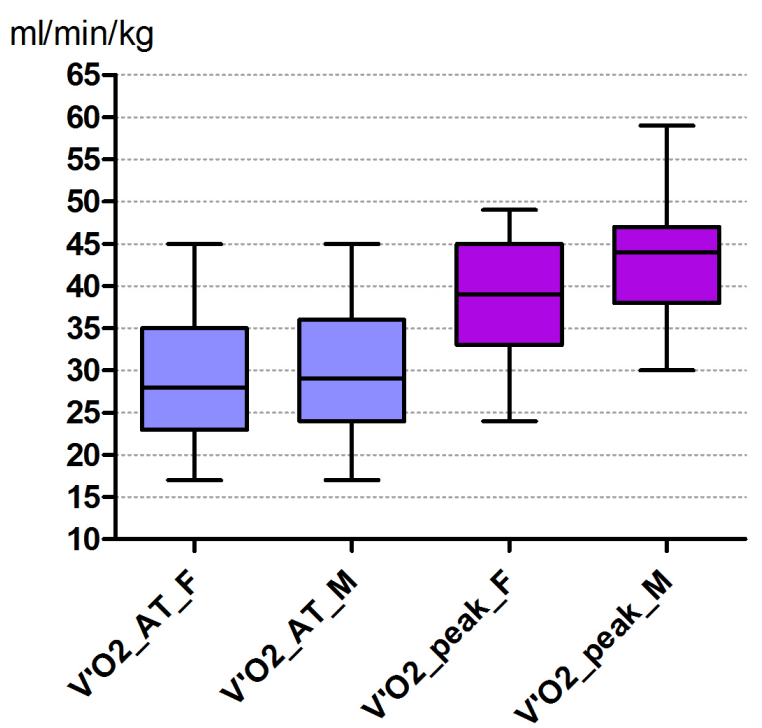

Figure 1. Anaerobic treshold (VO2_AT) and peak oxygen uptake (V'O2 2 peak) in males (M) and females (F) Romanian elite junior tennis players

The peak oxygen uptake of the Romanian elite junior tennis players are lower than international compe- 
titive tennis athletes, with a mean $\mathrm{V}^{\prime} \mathrm{O} 2$ peak of 43.2 $\mathrm{ml} / \mathrm{min} / \mathrm{kg}$ in males and $38.4 \mathrm{ml} / \mathrm{min} / \mathrm{kg}$ in females. This may be due to poor accessibility to testing and training facilities with a big impact on sports performance. (Figure 1)

Metabolic equivalents for oxygen and carbon dioxide (VE/V'O2 and VE/V'CO2) are both important indices of respiratory performance during exercise. We found that there are no significant differences between metabolic respiratory equivalents in male and female elite junior tennis players. (Figure 2)

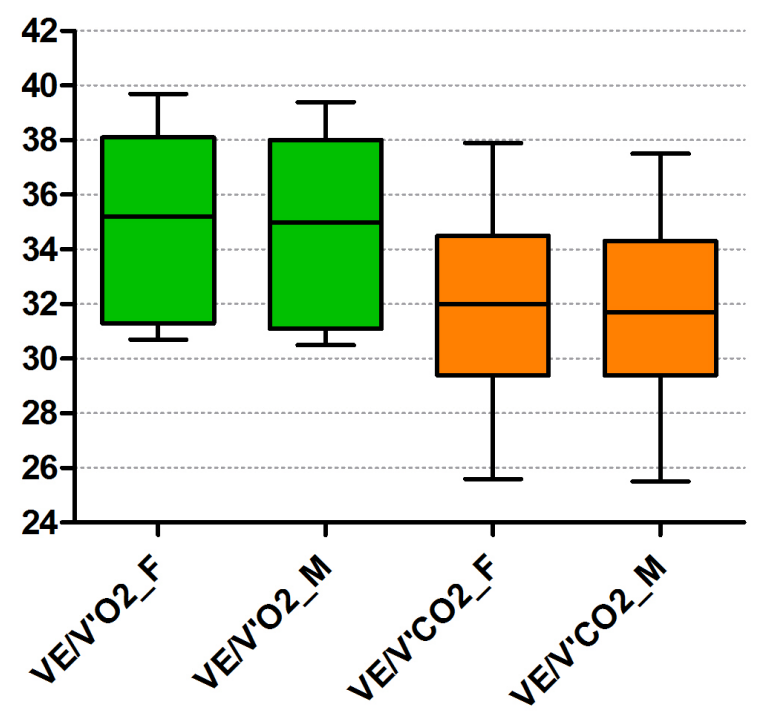

Figure 2. Metabolic equivalents for oxygen (VE/ $\left.\mathrm{V}^{\prime} \mathrm{O} 2\right)$ and carbon dioxide and (VE/V'CO2) in males (M) and females (F) Romanian elite junior tennis players

Strength is required in arm and forearm muscles of a tennis player, both for performance (ball velocity) enhancement and to reduce injuries (protection of joints, ligaments, tendons) [1]. During the tennis serve, it has been shown that the greatest contribution to final speed of the racket was provided by: upper arm internal rotation, wrist flexion, upper arm horizontal adduction, forearm flexion, and forward movement of the shoulder $[1,6,7]$.
Regarding strength performance evaluation in our study we found significant differences between males and females isometric strength during forearm flexion (56\%), arm internal rotation (59\%) and arm abduction (43\%). (Figure 3)

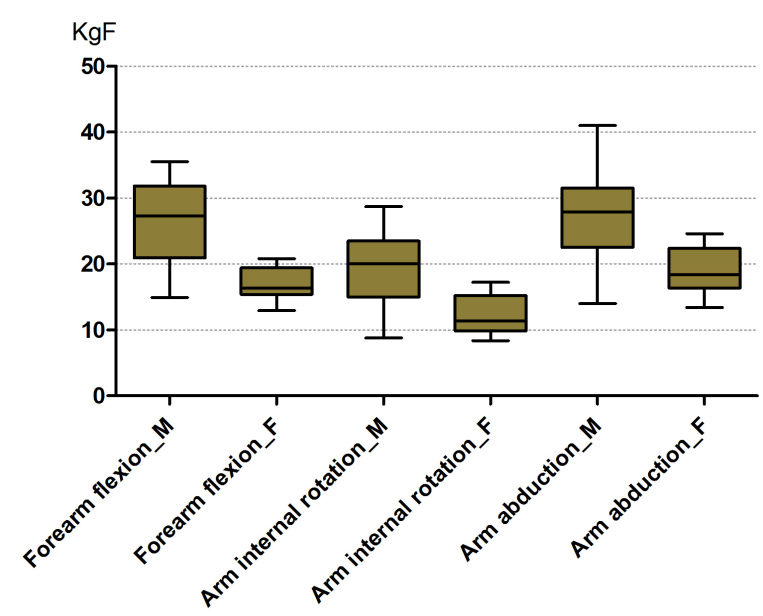

Figure 3. Strength performance evaluation or the three most important muscle groups from the dominant side of the males (M) and females (F) Romanian elite junior tennis players

Most of tennis injuries have been reported to occur in the lower body. Therefore is very important to include lower body strengthening exercises for tennis players. Even there were found significant differences between left and right upper limbs strength, lower body strength have been shown to be symmetrical in tennis players $[1,8,9]$.

Evaluation of lower limbs strength and power performance in our study have shown significant differences between genders regarding jump height (29\%, $p=0.002)$ but not for explosive power $(46 \%$, $\mathrm{p}=0.072$ ). (Figure 4)

Tennis is a sport based on unpredictability. Every shot of the opponent can have a different velocity, spin and be placed in different parts of the court. This complexity requires tennis athletes to have fast reaction times $[1,10]$. 


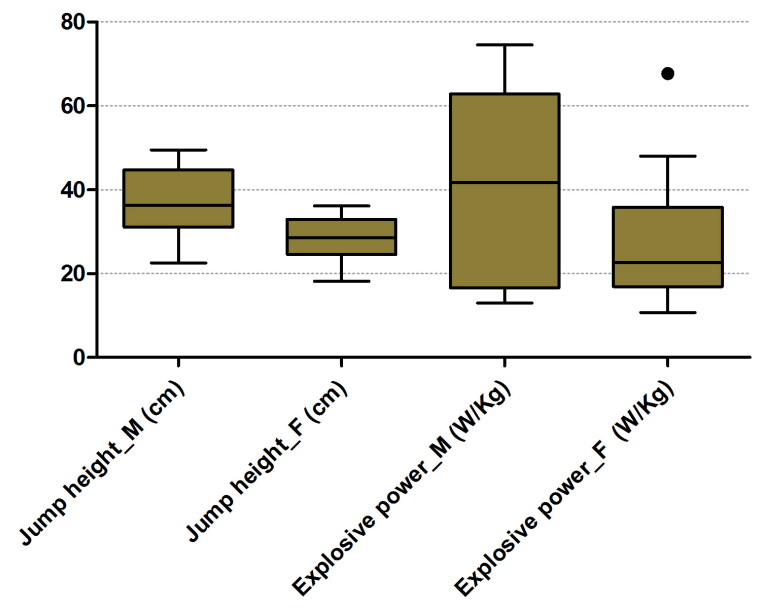

Figure 4. Lower limbs muscular performance in males (M) and females (F) Romanian elite junior tennis players

Simple reactions of a human body is depending on the overall speed of the perceptual and motor systems and is genetically determined [11]. There are significant differences between males and females in regard to simple reaction time, but there is no difference between novice and expert sportsmen [11, 12]. Comparing to simple reactions, the complex reactions (involving an important part of the body) might be influenced by specific training. In our study we found that the male and female group were quite homogenous (the coefficient of variation was only $2.6 \%$ for males and $4.3 \%$ for females) in regard to time reaction to random optic and acoustic stimulus. The mean time reaction of males was 1.34 seconds and 1.48 seconds for females, the difference being statistically significant $(p<0.001)$. (Table I and Table II)

\section{Conclusions}

The mean values of functional parameters of the Romanian elite junior tennis players are lower than international competitive tennis athletes. There are significant gender differences in junior tennis players, most of them being genetically influenced. We hope that the present study results provide useful reference values for coaches and physical trainers in order to improve functional performance of their junior tennis players. Further studies on larger groups of tennis players and parameters are needed in order to establish gender reference values of functional parameters in junior tennis players.

\section{References}

1. Kovacs M. (2006) Applied physiology of tennis performance. Brit J Sport Med, 40:381-386;

2. Torres-Luque G., Sánchez-Pay A., Bazaco M.J., Moya M. (2011) Functional aspects of competitive tennis. J. Hum. Sport Exerc. Vol. 6, No. 3, pp. 528-539;

3. Wasserman K., Hansen J.E., Sue D.Y., et al, (2007) Principles of exercise testing and interpretation. Philadelphia, Lippincott Williams \& Wilkins, USA;

4. Kovacs M. (2007). Tennis physiology. Training the competitive athlete. Sports Med, 37(3):189-198;

5. Therminarias A., Dansou P., Chirpaz-Oddou M., Quirino A. (1990) Effects of age on heart rate response during a strenuous match of tennis. J Sport Med Phys Fit, 30:389-396;

6. Elliott B.C., Marshall R.N., Noffal G.J. (1995) Contributions of upper limb segment rotations during the power serve in tennis. J Appl Biomech, 11:433-442;

7. Sprigings E., Marshall R., Elliott B., et al. (1994) A three-dimensional kinematic method for determining the effectiveness of arm segment rotations in producing racket head speed. J Biomech, 27:245-254;

8. Bylak J., Hutchinson M.R. (1998) Common sports injuries in young tennis players. Sport Med, 26:119-132;

9. Ellenbecker T.S., Roetert E.P. (1995) Concentric isokinetic quadriceps and hamstring strength in elite junior tennis players. Isokinet Exerc Sci, 5:3-6;

10. Groppel J.L. (1986) The biomechanics of tennis: an overview. Int J Sport Biomech, 2:141-155;

11. Mero A., Jaakkola L., Komi P.V. (1989) Neuromuscular, metabolic and hormonal profiles of young tennis players and untrained boys. J. Sport Sci, 7:95-100;

12. Nielsen D., Mcgown C. (1985) Information processing as a predictor of offensive ability in baseball. Percept. Mot. Skills, 60:775-781. 